\title{
Cholesterol and vitamin E determination in broiler chickens fed canola oil
}

\author{
Determinación de colesterol y vitamina E en pollos broiler alimentados con aceite de canola
}

\author{
MA Gallardo ${ }^{\mathrm{a}, \mathrm{b}^{*}}$, D Pérez $^{\mathrm{c}}$, P Strobel $^{\mathrm{d}}, \mathbf{J}$ Cárcamo $^{\mathrm{e}}$, F Leighton $^{\mathrm{c} \dagger}$ \\ ${ }^{a}$ Facultad de Agronomía, Pontificia Universidad Católica de Chile, Santiago, Chile. \\ bEscuela de Graduados, Facultad de Ciencias Veterinarias, Universidad Austral de Chile, Valdivia, Chile. \\ 'Laboratorio de Nutrición Molecular y Enfermedades Crónicas, Pontificia Universidad Católica de Chile, Santiago, Chile. \\ ${ }^{\mathrm{d} I n s t i t u t o ~ d e ~ C i e n c i a ~ A n i m a l, ~ U n i v e r s i d a d ~ A u s t r a l ~ d e ~ C h i l e, ~ V a l d i v i a, ~ C h i l e . ~}$ \\ eInstituto de Bioquímica y Microbiología, Facultad de Ciencias, Universidad Austral de Chile, Valdivia, Chile.
}

\begin{abstract}
RESUMEN
Este estudio describe el efecto del aceite de canola sobre las proporciones de colesterol y vitamina $\mathrm{E}$ ( $\alpha$ and $\gamma$ tocopherol) en piernas y pechugas de pollos broiler. Ciento veinte pollos broiler de $1 \mathrm{~d}$ de edad fueron aleatoriamente asignados dentro de cuatro grupos de 32 pollos cada uno. Cada grupo fue dividido en cuatro subgrupos de ocho pollitos, los que recibieron una de las cuatro dietas conteniendo: $15 \%$ de aceite con diferentes porcentajes de aceite de canola (dieta 1: 0\%; 2: 5\%; 3: 10\%; y 4: 15\%) por 31 días. Los animales fueron sacrificados al día 45 para la obtención de muestras. Colesterol en piernas y $\gamma$ tocoferol en piernas y también en pechugas no mostraron una tendencia clara acorde incrementaba el contenido de aceite de canola y decrecía el de aceite de maíz en las dietas (a pesar de las mayores proporciones de $\gamma$ tocoferol encontradas en el aceite de maíz). En conclusión las proporciones de vitamin E encontradas en el aceite de canola no influenciaron las proporciones de vitamina E en el tejido muscular en pollos broiler.
\end{abstract}

Palabras clave: antioxidantes: $\alpha$ tocoferol, $\gamma$ tocoferol, carne de pollo.

\section{SUMMARY}

This article describes the effect of canola oil on cholesterol and vitamin E ( $\alpha$ and $\gamma$ tocopherol) proportion in broiler chicken legs and breast. One hundred and twenty eight 1-day old broiler chickens were randomly assigned into 4 groups of 32 chicks each. Each group was divided into 4 subgroups of 8 chicks which received one of the four diets containing 15\% oil with different percentages of canola oil (diet 1: $0 \%$; 2 : 5\%; 3 : 10\%; and 4: 15\%) for 31 days. Animals were sacrificed at day 45 to obtain samples. Cholesterol in legs and $\gamma$ tocopherol in legs and also chicken breast did not show a clear trend according increased canola and decreased corn oil in the diets (despite of the higher $\gamma$ tocopherol proportions found in corn oil). In conclusion vitamin E proportions found in canola oil did not influence vitamin E proportions in muscle tissue in broiler chickens.

Key words: antioxidants, $\alpha$ tocopherol, $\gamma$ tocopherol, chicken meat.

\section{INTRODUCTION}

The increased $\omega 6 / \omega 3$ ratio and cholesterol contents coupled with the decreased antioxidants in the diet has contributed to increase the incidence of chronic diseases in human such as coronary artery disease, hypertension, type 2 diabetes, arthritis, inflammatory and autoimmune disorders and cancer (WHO 2002). It is known that consumption of saturated fatty acids (SFA) promotes the increase of cholesterol storage, while unsaturated fatty acid consumption can protect against cholesterol storage (Nettleton 2006).

In constrast to some vegetable oils such corn oil (rich in $n$-6 polyunsaturated fatty acids, $n$ - 6 PUFA), there is canola oil, a vegetable oil high in monounsaturated (MUFA) and

\footnotetext{
Accepted: 02.10.2014.

* mugallar@gmail.com

$\dagger \quad$ In memoriam.
}

$n$-3 PUFA, which reduces $n-6 / n-3$ ratio in chicken meat (Gallardo et al 2012) and plasma cholesterol in human (Kris-Etherton et al 1999), with potential benefits on cardiovascular health.

Meat susceptibility to oxidation depends on the number of double bonds (over three) present in the fatty acids, pro-oxidants compounds (containing iron) and antioxidants proportions such as vitamin $\mathrm{C}$ and $\mathrm{E}$. The unsaturation degree in the phospholipids subcellular membrane is an important determinant of the oxidative stability in meat, with chicken meat showing a higher unsaturation degree than red meat due to their higher phospholipids content (Luciano et al 2011).

Our hypothesis is that vitamin E proportions present in canola oil should modify cholesterol and vitamin E proportions in chicken meat. The objective of this study was to determine the effect of canola oil on cholesterol and vitamin E proportions ( $\alpha$ and $\gamma$ tocopherol) in chicken legs and breast. 


\section{MATERIAL AND METHODS}

This study was performed in the Metabolic Unit of the Agriculture Faculty of the Pontificia Universidad Católica de Chile. One hundred and twenty eight 1-day old males and females Cobb broiler chicks were randomly assigned to four groups of 32 chicks. Each 32 chicks were subdivided into four subgroups of eight chicks per cage. The cage containing eight chicks represented the experimental unit. Each treatment had four replicates.

Treatments consisted in four experimental diets supplied as grower and finisher diets. In fresh base, each diet included $15 \%$ of total oil (canola, corn oil or both): diet $1,15 \%$ corn oil (control diet); diet 2, 5\% canola oil plus $10 \%$ corn oil; diet 3, $10 \%$ canola oil plus $5 \%$ corn oil; $\operatorname{diet} 4,15 \%$ canola oil. Oils were stored in a cold chamber between $0-5^{\circ} \mathrm{C}$.

The consumption period for each experimental diet was defined following the broiler chicken growth curve. Chicks assigned to each experimental diet consumed a starter diet for 14 days, a grower diet (diets 1 to 4 ) for another 14 days and a finisher diet (diets 1 to 4 ) for the last 17 days.

The starter diet (a commercial diet, oil free) was the same for each group. The grower and finisher diets (table 1) were based on Glycine híspida (soybean bran), Zea mais (corn grain) and tricalcium phosphate, and $15 \%$ added oil. The formulations were based on the minimum requirements and diet contribution according to the chicks age (NRC 1994).

To increase energy/ protein ratio $(\mathrm{E} / \mathrm{P})$ in the experimental diets, soybean bran was added at a level of $35 \%$ of dry matter taking into account the detrimental effects of trypsin inhibitors on growth rate in chicks, but achieving an optimal diet to study the effect of canola oil on broiler meat.

After $45 \mathrm{~d}$, broilers were sacrificed using manual neck breaking technique. Fat free meat samples (legs and breast) were deboned, homogenized for $30 \mathrm{~s}$ with a Moulinex ${ }^{\odot}$ meat chopper appliance and stored in hermetically sealed bags at $-20{ }^{\circ} \mathrm{C}$ until their analysis.

Cholesterol was determined by Folch methodology using $0.5 \mathrm{~g}$ samples, which were saponified with pyrogallol, extracted with hexane and derivatized by trimethylsilylation (TMC/ BSA). The derivative was injected into a gas chromatograph Carlo-Erba Instruments Modelo: GC 6000 Vega Series 2 with FID detector. Modified protocol of Official Methods of Analysis (AOAC 1990). Cholesterol was determined according to the Official Chilean Standard (NCh 1858 of 81 1981).

Vitamin $\mathrm{E}$ ( $\alpha$ and $\gamma$ tocopherol proportions) in oils and meat were measured using HPLC (Merck Hitachi L-6000 pump) with electrochemical detector (BAS Amperometric Detector Lc-4C). Oil (50 ul) and meat samples (1 g) were homogenised in ethanol, pyrogallol, BHT mixture, extracted with hexane and redissolved in ethanol: methanol using methodology described by Ruperez et al (1998).

Vitamin E proportions in oils and chicken legs and breast, and cholesterol proportions in chicken legs and breast, were analysed using a one-way ANOVA, comparing the two oils, the four diets and the two tissues (legs and breast), using GLM procedure from SAS (version 9.1.3, SAS Institute Inc., 2006). Least square means were estimated and multiple range tests were performed to assess significant differences between means for the four diets. The statistical model used was $y i j=\mu+A i+\varepsilon i j$, where: $y i j=$ observation $j$ in level $i$ of factor $A ; \mu=$ the overall mean; $A i=$ the fixed effect of level $i$ of diet; $\varepsilon i j=$ random error.

\section{RESULTS AND DISCUSION}

Vitamin E proportions ( $\alpha$ and $\gamma$ tocopherol) in canola and corn oil (table $2 \mathrm{~A}$ ) were within the range reported by Norma Codex Standard 1999. $\gamma$ tocopherol was significantly higher in corn than canola oil $(\mathrm{P}<0.0001)$, explained by the lower oxidation values reported for this oil (Gallardo et al 2012).

Table 2B shows cholesterol and vitamin E proportions ( $\alpha$ and $\gamma$ tocopherol) in chicken legs and breast. Cholesterol proportions in legs showed significant differences between diets $(P=0.04)$ without a trend to relate their content with the type of predominant oil present in the diet. Comparing muscles from legs and breast, cholesterol values were higher in legs than in chicken breast $(\mathrm{P}=0.02)$.

Table 1. Ingredients ( $\%$ of fresh weight) of the grower and finisher diets in broiler chickens. Ingredientes (\% de peso fresco) de las dietas de crecimiento y finalización en pollos broiler.

\begin{tabular}{lcccccccc}
\hline \multirow{2}{*}{ Ingredients } & \multicolumn{4}{c}{ Grower diet } & \multicolumn{4}{c}{ Finisher diet } \\
\cline { 2 - 9 } & Diet 1 & Diet 2 & Diet 3 & Diet 4 & Diet 1 & Diet 2 & Diet 3 & Diet 4 \\
\hline Soybean bran & 49,62 & 49,62 & 49,62 & 49,62 & 36,74 & 36,74 & 36,74 & 36,74 \\
Corn grain & 31,94 & 31,94 & 31,94 & 31,94 & 45,10 & 45,10 & 45,10 & 45,10 \\
T. Phosphate1 & 3,34 & 3,34 & 3,34 & 3,34 & 3,06 & 3,06 & 3,06 & 3,06 \\
Corn Oil & 15,00 & 10,00 & 5,00 & 0,00 & 15,00 & 10,00 & 5,00 & 0,00 \\
Canola Oil & 0,00 & 5,00 & 10,00 & 15,00 & 0,00 & 5,00 & 10,00 & 15,00 \\
\hline
\end{tabular}

1 T. Phosphate: Tricalcium phosphate. 
Table 2. Vitamin E content ( $\alpha$ and $\gamma$ tocopherol, $\mathrm{mg} / \mathrm{kg}$ ) in canola and corn oil (2A) and cholesterol content ( $\mathrm{mg} / 100 \mathrm{~g}$ ), $\alpha$ and $\gamma$ tocopherol ( $\mathrm{mg} / \mathrm{kg}$ ) in legs, chicken breast and comparison between muscles (legs and breast) (2B).

Contenido de vitamina $\mathrm{E}$ ( $\alpha$ y $\gamma$ tocoferol, $\mathrm{mg} / \mathrm{kg}$ ) en el aceite de canola y maíz (A) y contenido de colesterol (mg/100 g), $\alpha$ y $\gamma$ tocoferol $(\mathrm{mg} / \mathrm{kg})$ en piernas y pechugas de pollos broiler y comparación entre músculos (piernas y pechuga) (2B).

A)

\begin{tabular}{lccc}
\hline $\begin{array}{l}\text { Vitamin E } \\
\text { LSM } \pm \text { SEM }\end{array}$ & $\begin{array}{c}\text { Corn } \\
(\mathrm{n}=3)\end{array}$ & $\begin{array}{c}\text { Canola } \\
(\mathrm{n}=3)\end{array}$ & $\mathrm{P}^{1}$ \\
\hline$\alpha$ Tocopherol & $166.4^{\mathrm{b}} \pm 13.77$ & $226.7^{\mathrm{a}} \pm 3.76$ & 0.01 \\
$\gamma$ Tocopherol & $640.6^{\mathrm{a}} \pm 6.40$ & $342.0^{\mathrm{b}} \pm 7.95$ & $<.0001$
\end{tabular}

B)

\begin{tabular}{|c|c|c|c|c|c|}
\hline $\begin{array}{l}\text { Legs } \\
\mathrm{LSM} \pm \mathrm{SEM}\end{array}$ & $\begin{array}{l}\text { Diet 1 } \\
(\mathrm{n}=4)\end{array}$ & $\begin{array}{l}\text { Diet } 2 \\
(\mathrm{n}=4)\end{array}$ & $\begin{array}{l}\text { Diet 3 } \\
(\mathrm{n}=4)\end{array}$ & $\begin{array}{l}\text { Diet } 4 \\
(\mathrm{n}=4)\end{array}$ & $\mathrm{P}^{2}$ \\
\hline Cholesterol & $917.4^{\mathrm{ab}} \pm 37.8$ & $1056.6^{\mathrm{a}} \pm 59.6$ & $838.9^{b} \pm 67.4$ & $1028.4^{\mathrm{a}} \pm 31.2$ & 0.04 \\
\hline$\alpha$ Tocopherol & $1.97 \pm 0.38$ & $2.97 \pm 0.81$ & $1.55 \pm 0.26$ & $2.34 \pm 0.33$ & 0.27 \\
\hline$\gamma$ Tocopherol & $0.58^{b} \pm 0.19$ & $1.34^{\mathrm{a}} \pm 0.24$ & $0.75^{\mathrm{b}} \pm 0.13$ & $1.51^{\mathrm{a}} \pm 0.22$ & 0.02 \\
\hline \multicolumn{6}{|l|}{ Breast } \\
\hline Cholesterol & $628.5 \pm 25.6$ & $687.8 \pm 40.5$ & $659.4 \pm 8.7$ & $641.9 \pm 22.6$ & 0.47 \\
\hline$\alpha$ Tocopherol & $1.87 \pm 0.32$ & $2.02 \pm 0.97$ & $1.85 \pm 0.47$ & $2.86 \pm 0.72$ & 0.16 \\
\hline$\gamma$ Tocopherol & $0.53 b^{c} \pm 0.18$ & $0.97^{\mathrm{ab}} \pm 0.12$ & $0.45^{\mathrm{c}} \pm 0.14$ & $1.28^{\mathrm{a}} \pm 0.19$ & 0.01 \\
\hline Between muscles & Legs & Breast & $\mathrm{P}^{3}$ & $\mathrm{P}^{4}$ & \\
\hline Cholesterol & $960.3^{a} \pm 64.26$ & $654.39^{b} \pm 26,59$ & 0.02 & 0.07 & \\
\hline$\alpha$ Tocopherol & $2.21 \pm 0.51$ & $2.15 \pm 0.37$ & 0.84 & 0.34 & \\
\hline$\gamma$ Tocopherol & $1.05 \pm 0.27$ & $0.81 \pm 0.23$ & 0.07 & 0.82 & \\
\hline
\end{tabular}

1 P value comparing between oils.

2 P value between treatments.

3 P value between muscles (legs and breast).

$4 \mathrm{P}$ value interaction diet $\mathrm{x}$ muscle.

For cholesterol, Kalogeropoulos et al (2010) reported values for breast and chicken legs of 456.2 and $638.9 \mathrm{mg} /$ $\mathrm{kg}$ respectively (higher than those reported in this study). Cholesterol proportions were higher in legs than in chicken breast, because of the higher total fat percentages found in legs (Gallardo et al 2012).

Contrary to our results, it have been reported that diets rich in MUFA (Kris-Etherton et al 1999) and PUFA (Newman et al 2002) such canola oil is, decreased plasma cholesterol in birds and human. Also, Crespo and EsteveGarcia (2002) working with female broiler fed different types of fat (10\% fat, olive oil, sunflower and linseed) determined that cholesterol in legs was lower in diets containing sunflower or linseed oil (high in PUFA) than in diets containing fat (SFA) or olive oil (high in MUFA), due to the increase in lipid oxidation by an increased endogenous lipogenesis.

Regarding to vitamin E, no significant differences in $\alpha$ tocopherol proportions were found between diets and muscles. Kalogeropoulos et al (2010) reported $\alpha$ tocopherol values between 7.23 and $4.54 \mathrm{mg} / \mathrm{kg}$ for legs and breast respectively (higher than those reported in our study). Same authors reported $\gamma$ tocopherol values between 0.58 and $0.38 \mathrm{mg} / \mathrm{kg}$ for legs and breast respectively (lower compared to those found in this study). $\gamma$ tocopherol proportions in legs and breast did not show a trend to relate their content with the type of predominant oil present in the diet. Comparing muscle tissues, no significant differences in $\alpha$ or $\gamma$ tocopherol proportions were found.

Gatellier et al (2000) reported that oils containing vitamin E protected meat against lipid oxidation. Vitamin E should inhibit peroxidation from PUFA having less than 20 carbons and three double bonds more than from MUFA or SFA, playing a more important role in oxidative stability than the increase in MUFA/SFA ratio (Hsieh et al 2002). However, the same authors reported that $\alpha$ tocopherol was not affected by dietary increase in MUFA/SFA ratio, similar observation found in our experiment when faced our $\alpha$ tocopherol results with the MUFA/SFA proportions reported by Gallardo et al (2012), working with the same animals and treatments.

Finally, although Zanini et al (2003) reported that canola oil should allow higher storage of vitamin $E$ in meat than fish oil, in our experiment canola and corn oil had similar effect on vitamin E storage. 
In conclusion, cholesterol proportion in legs and $\gamma$ tocopherol proportion in chicken legs and breast did not show a clear trend according increased canola and decreased corn oil contents of diets (despite of the high $\gamma$ tocopherol levels found in corn oil). Vitamin E proportions found in canola oil did not influence vitamin E proportions found in muscle tissue from legs and breast in broiler chickens.

\section{ACKNOWLEDGEMENTS}

This study was financed by Ciencia Vino Salud Project (PUCPBMEC2003).

\section{REFERENCES}

AOAC, Association of Official Analytical Chemists. 1990. Official methods of analysis. $15^{\text {th }} \mathrm{ed}$. Gaithersburg, VA, USA.

Crespo N, E Esteve-García. 2002. Dietary polyunsaturated fatty acids decrease fat deposition in separable fat depots but not in the remainder carcass. Poult Sci 81, 512-518.

Gallardo MA, D Perez, F Leighton. 2012. Modification of fatty acid composition in broiler chickens fed canola oil. Biol Res 45, 159-171.

Gatellier P, Y Mercier, E Rock, M Renerre. 2000. Influence of dietary fat and vitamin $\mathrm{E}$ supplementation on free radical production and on lipid and protein oxidation in turkey muscle extracts. J Agric Food Chem 48, 1427-1433.

Hsieh HF, SH Chiang, MY Lu. 2002. Effect of dietary monounsaturated/ saturated fatty acid ratio on fatty acid composition and oxidative stability of tissue in broilers. Anim Feed Sci Technol 95, 189-204.

Kalogeropoulos N, A Chiou, E Gavala, M Christea, NK Andrikopoulos. 2010. Nutritional evaluation and bioactive microconstituents (carotenoids, tocopherols, sterols and squalene) of raw and roasted chicken fed on DHA-rich microalgae. Food Res Int 43, 2006-2013.

Kris-Etherton P, T Pearson, Y Wan, R Hargrove, K Moriarty, V Fishell, D Etherton. 1999. High-monounsaturated fatty acid diets lower both plasma cholesterol and triacylglycerol concentrations. Am J Clin Nutr 70, 1009-1015.

Luciano A, P Moloney, A Priolo, FT Röhrle, V Vasta, L Biondi, P LópezAndrés, S Grasso, FJ Monahan. 2011. Vitamin E and PUFA in bovine muscle and the oxidative stability of beef from cattle receiving grass or concentrate-based rations. J Anim Sci 89, 3759-3768.

NCh 1858 Of 81, Norma Chilena Oficial. 1981. Cuerpos grasos de origen animal y vegetal. Detección de grasas animales en aceites y grasas vegetales. Determinación de Colesterol. Norma Codex STAN 210-1999. Aceites Vegetales Especificados.

Nettleton JA, LM Steffen, EJ Mayer-Davis, NS Jenny, R Jiang, DM Herrington, DR Jacobs. 2006. Dietary patterns are associated with biochemical markers of inflammation and endothelial activation in the multi-ethnic study of atherosclerosis (mesa). Am J Clin Nutr 83, 1369-1379.

Newman R, W Bryden, E Fleck, J Ashes, W Buttemer, L Storlien, J Downing. 2002. Dietary n-3 and n-6 fatty acids alter avian metabolism: metabolism and abdominal deposition. Br J Nutr 88, 11-18.

NRC, National Research Council. 1994. Nutrient requirements of poultry. $9^{\text {th }}$ rev. ed. National Academy Press, Washington, DC., USA.

Rupérez FJ, C Barbas, M Castro, S Martínez, E Herrera. 1998. Simplified method for vitamin $\mathrm{E}$ determination in rat adipose tissue and mammary glands by high-performance liquid chromatography. J Chromatogr 823, 483-487.

SAS Institute Inc. 2006. Base SAS 9.1.3 Procedures Guide. Vol. 1, 2, 3 and 4. $2^{\text {nd }}$ ed. Statistical Analysis Systems Institute Inc., Cary, NC, USA.

WHO, World Health Organization. 2004. Diet, nutrition and the prevention of chronic diseases. Public Health Nutr 7.

Zanini SF, CA Torres, N Bragagnolo, JM Turatti, MG Silva, MS Zanini. 2003. Lipid composition and vitamin E concentration in cockerel meat. LWT-Food Sci Technol 36, 697-702. 